\title{
Determining Optimum Shear Strength of Friction Stir Spot Welding Parameters of AA1050/C10100 Joints
}

\author{
Ali Habibizadeh (ORCID: 0000-0003-1100-4464), Mohammad Honarpisheh (ORCID: 0000-0002-5331-5300), \\ Sa'id Golabi (ORCID: 0000-0003-1781-023X) \\ Faculty of Mechanical Engineering, University of Kashan. Qotb-e Ravandi Blvd, Kashan 8731753153. Isfahan. E- \\ mail: Habibizadeh.a@saipa-citroen.com, Honarpishe.a@kashanu.ac.ir, golabi-s@kashanu.ac.ir
}

In this paper, lap joint of $2 \mathrm{~mm}$ thickness AA1050 sheets and C10100 sheets using different process parameters were investigated. Experimental plan is designed according to response surface methodology (RSM) where: tool rotation speed, plunge depth and dwell time vary between 500 and $2500 \mathrm{rpm}, 2.1$ and $3.7 \mathrm{~mm}$ and 0 and $8 \mathrm{~s}$ respectively. The main affecting and interaction process parameters are evaluated using analysis of variance (ANOVA) methodolgy. Mathematical models describing the relationship between welding parameters and shear failure load (SFL) are developed and the optimal FSSW parameters are specified. Design expert software is used for optimization of friction stir spot welding process parameters using response graphs and contour plots. With 95\% confidence level, shear failure load of the dissimilar Al 1050- Cu 10100 joints are predicted using the developed empirical relations. It is found that the optimal results of the SFL is close to the optimal solution obtained from the mathematical model with less than $4 \%$ discrepancy.

Keywords: Friction Stir Spot Welding, AA1050, C10100, RSM, Optimization

\section{Introduction}

Considering required material properties for design engineers form one hand and the cost of materials from the other hand lead to the application of joined dissimilar materials in various machine parts and industrial applications (Li et al., 2020; Dobrocky et al.,2018). Aluminum (Al) alloys are attractive lightweight structural materials with low density, good stiffness, good corrosion resistance and recycling capability which make them an ideal candidate to replace heavier materials (Miller et al., 2000). Due to their special properties such as excellent combination of strength and ductility, high thermal and electrical conductivity, corrosion and wear resistance, copper $(\mathrm{Cu})$ and copper alloys have attracted considerable attraction in industrial applications (Heidarzadeh et al., 2018; Sahlot et al., 2019). In many industries, requirement for the properties of both $\mathrm{Cu}$ and $\mathrm{Al}$ alloys increased the demands for sound welding and joining of $\mathrm{Cu}$ to $\mathrm{Al}$ alloys (Li et al., 2020).

The joint between $\mathrm{Cu}$ and $\mathrm{Al}$ via fusion welding processes is often problematic as there is a significant difference between their melting temperature and physical-chemical properties, and brittle intermetallic compounds (IMCs) are inevitably formed at the joints interface (Pérez et al., 2019; SIDDHARTH et al., 2017). The weight of bolts and rivets during mechanical joining of two metals increases the weight of the structure, and the pre-drilled holes cause stress con- centration and deteriorate the structure's fatigue strength (Sejč et al., 2020). In addition, Al-Cu joints' robust electrical conductivity can hardly be accomplished by mechanical joining method ( $\mathrm{Li}$ et al., 2020). Hence conventional friction stir spot welding (FSSW), which is a type of friction stir welding (FSW), was developed as an effective alternative for riveting and resistance spot welding (RSW) (Mubiayi et al., 2019). Friction stir spot welding is a solid state welding technique used commonly to join different types of materials. The method uses a non-consumable spinning tool plunged into the sheets that proposed to be attached, mostly in lap configuration; and kept in that location for a limited time (the dwell time) after reaching a specified plunge depth (Mubiayi et al., 2019).

Over the years, many researches have been researched to produce friction stir spot welds between aluminum and copper (Abbass, Muna K., Sabah Kh Hussein, 2015; Garg \& Bhattacharya, 2017; Heideman et al., 2010; Manickam \& Balasubramanian, 2015; MUBIAYI \& AKINLABI, 2016; Özdemir et al., 2012; Shiraly et al., 2014, 2017; SIDDHARTH et al., 2017; Siddharth \& Senthilkumar, 2017, 2018; Sun et al., 2017). The strength of welds is mainly influenced by process parameters, i.e., tool rotation speed, plunge depth, tool design, and dwell time. Forgetting the tool effects, the key parameters are: dwell time, tool rotation speed and dip depth (Pérez et al., 2019). Throughout the FSSW process, tool penetration depth and dwell time fundamentally affects the generated heat, 
material plasticization around the tool's pin, weld geometry and, hence, the mechanical properties of welded joints (Kastih et al., 2017). If the process parameters are well chosen, sound spot welds are obtained. These parameters have been studied by various researchers to investigate their effects on fabricated spot welds and to achieve spot-free welding (Mubiayi et al., 2019).

Heideman et al. (Heideman et al., 2010), welded a $1.5 \mathrm{~mm} 6061$-T6 aluminum sheet on top to a $1.5 \mathrm{~mm}$ oxygen free pure copper sheet on the bottom in lap configuration, using a threaded and pre-hardened H13 tool steel pin (42-46 HRC) with concave shoulder design. The rotational speed ranged from 1000 to 2000 $\mathrm{rpm}$. Two different plunge depths were used, namely 0.0 and $0.13 \mathrm{~mm}$. In addition, they used two separate dwelling times, i.e., 3 and $6 \mathrm{~s}$. Their findings show that the rotational speed influences the weld strength very significantly, e.g. rotational speed of $2000 \mathrm{rpm}$ produces somehow stronger weld than that made with 1000 $\mathrm{rpm}$. However, the average weld strength at $3000 \mathrm{rpm}$ with a pin length of $2.60 \mathrm{~mm}$, was found to be identical to those produced at $2000 \mathrm{rpm}$, possibly due to tool slippage occurring at higher rotational speed. The depth of plunge was also found to be the other important parameter. The effect of plunge depth was especially more evident with a pin length of $1.83 \mathrm{~mm}$ and rotation speed of $2000 \mathrm{rpm}$ whereas increasing the plunge depth from 0.00 to $0.13 \mathrm{~mm}$ increased the average weld strength from 702 to $1533 \mathrm{~N}$.

Mubiayi and Akinlabi (MUBIAYI \& AKINLABI, 2016) FSS welded 1060 aluminum alloy (AA) to C11000 copper, using a H13 tool steel hardened to HRC 50-52. The spot welds were produced using two separate tool features: a flat pin and a flat shoulder, as well as a conical pin and a concave shoulder. Two rotational speeds were used, i.e., 800 and $1200 \mathrm{rpm}$; while the two shoulder plunge depths of 0.5 and $1 \mathrm{~mm}$ were used. The results showed that with an increase in shoulder plunge depth, the maximum tensile failure load increases, except for the weld produced at 800 rpm using a conical pin and a concave shoulder. Under the lap-shear loading conditions a nugget pull-out failure mode occurred in all the friction stir spot welds. Tensile failure load increases for a tool with conical pin and a concave shoulder geometry at a constant shoulder plunge depth, by increasing tool rotational speed.

Siddharth and Senthilkumar (Siddharth \& Senthilkumar, 2017) used a H13 tool steel with a cylindrical straight flat geometry to join $1.5 \mathrm{~mm}$ thick aluminum 5083 on top to a C10100 copper sheet with 1.25 to 2.75 thickness at bottom. The results revealed that the frictional stir created by the tool was not sufficient for the top and bottom sheets to be joined together when the plunge depth was less than $1.25 \mathrm{~mm}$. When the plunge depth was greater than $2.75 \mathrm{~mm}$, the chance of puncture of the top and bottom sheets was increased, resulting in excessive flash and wide keyholes.

The dwell time effect documented a bit contradictory. For the FSSW process of aluminum alloys, Zhang et al. (Zhang et al., 2011) stated that the joint tensile/shear strength decreases with increasing rotational speed, while it is not affected significantly by dwell time. On the other hand, Kulekci (Kulekci, 2014) stated that FSSW's tensile shear strength was significantly affected by dwelling time while the impact of dwelling time was negligible only with higher plunge depth and tool speed.

Many investigators (Chu et al., 2018; Colmenero et al., 2019; Jannet et al., 2015; Karthikeyan \& Balasubramanian, 2010; Klobčar, Tušek, Skumavc, et al., 2014; Klobčar, Tušek, Smolej, et al., 2014; Manickam \& Balasubramanian, 2015; R. Padmanaban, R. Vaira Vignesh, M. Arivarasu, 2016; Siddharth \& Senthilkumar, 2016; Suryanarayanan \& Sridhar, 2020) have focused on using design of experiments including response surface methodology (RSM) to optimize FSSW process parameters for joining similar and dissimilar alloys. RSM is a combination of experimental, regression analysis and statistical inferences. RSM not only decreases costs and time, but also provides required information about the interaction effects with minimum number of experiments (Mata et al., 2010). To estimate the mechanical strength of joints, the central composite design (CCD) mathematical model in RSM was used. RSM is a set of statistical and mathematical techniques useful for process development, enhancement and optimization. RSM's most extensive applications are in the industrial world, particularly where multiple input variables potentially influence product or process performance measures or quality characteristics.

This paper looks at the FSSW's efficient parameters across a wider spectrum comparing with other published articles. Also, the aluminum sheet is often placed above the copper sheet in most published papers in order to fabricate welds. However, according to a number of sources positioning the cooper sheet on the top leads to higher weld strength that needs to be investigated and validated. The effects of sheets and tools dimensions are also required to be studied. The goal of this study is to optimize the process parameters of friction stir spot welding of C10100 copper and AA1050 aluminum sheet with copper sheet on top in a lap joint using Response Surface Methodology (RSM).

\section{Materials and methods}

The materials, their properties and the steps of research used in this research are presented in this section. The dimensions of $2 \mathrm{~mm}$ Aluminum 
(AA1050) and oxygen free Copper (C10100) sheets are $100 \times 40 \mathrm{~mm}$ where $40 \mathrm{~mm}$ in length is overlapped for FSSW using H13 tool steel (heat treated to 46-52 HRC), as shown in Fig. 1. The sheets were cut to required size by guillotine machine and lap joined and locked using mechanical clamps. The chemical composition and tensile properties of the sheets are presented in Tables 1 and 2 respectively. Spot weld geometry of Fig. 1 was used to prepare test specimens according to ISO 14273. The spot overlap welds were produced using a CNC 100 machine. Since the tool shoulder works on the top plate surface, its material plays a vital role; therefore, the degree of softening due to generated heat depends on the physical property of the plate placed on top (R. Palanivel, I. Dinaharan, 2019). According to (Klobčar, Tušek, Smolej, et al., 2014), placing copper sheet on top leads to higher strength weld since $\mathrm{Al}$ would accept only "cold welding conditions" and the copper in below would also serve as a heatsink.

A tool having a conical pin and concave shoulder (CCS profile) with $2.5 \mathrm{~mm}$ length, $5 \mathrm{~mm}$ diameter and $14 \mathrm{~mm}$ shoulder diameter was employed, as shown in Fig. 2. The welding process setup with rotating tool and clamped sheets in fixture is shown in Fig. 3. The fabricated FSSW joints are shown in Fig. 4. After welding process, shear testing of the welds was carried out using a Koopa universal testing machine with a crosshead speed of $1 \mathrm{~mm} / \mathrm{min}$. In order to maintain loading alignment, shims as thick as the base materials sheets were used in the grips of the universal testing machine. The ultimate shear load endured by each weld was noted for further analysis. These loads were analyzed with analysis of variance (ANOVA) to identify the significant parameters.

Tab. 1 Chemical composition of the sheets

\begin{tabular}{|c|c|c|c|c|c|c|c|c|c|c|c|c|c|}
\hline \multirow[b]{2}{*}{ Material } & \multicolumn{13}{|c|}{ Composition (wt. \%) } \\
\hline & $\mathrm{Fe}$ & $\mathrm{Mg}$ & $\mathrm{Mn}$ & $\mathrm{Si}$ & $\mathrm{O}$ & $\mathrm{Zn}$ & $\mathrm{Pb}$ & Co & B & $\mathrm{Sb}$ & $\begin{array}{l}\text { Oth- } \\
\text { ers }\end{array}$ & $\mathrm{Cu}$ & $\mathrm{Al}$ \\
\hline $\begin{array}{l}\text { AA } \\
1050\end{array}$ & 0.33 & 0.02 & 0.01 & 0.048 & - & - & - & - & - & - & 0.03 & - & Bal. \\
\hline C10100 & 0.0008 & - & - & - & 0.0004 & 0.0002 & $<0.003$ & - & - & 0.0003 & - & Bal. & - \\
\hline
\end{tabular}

Tab. 2 Tensile properties of the aluminum and copper sheets

\begin{tabular}{cccc}
\hline & Yield stress $(\mathrm{MPa})$ & Tensile Strength $(\mathrm{MPa})$ & Fracture Strength $(\mathrm{MPa})$ \\
\hline AA 1050 & 98.73 & 160.98 & 100.71 \\
C10100 & 132.03 & 251.38 & 137.98 \\
\hline
\end{tabular}

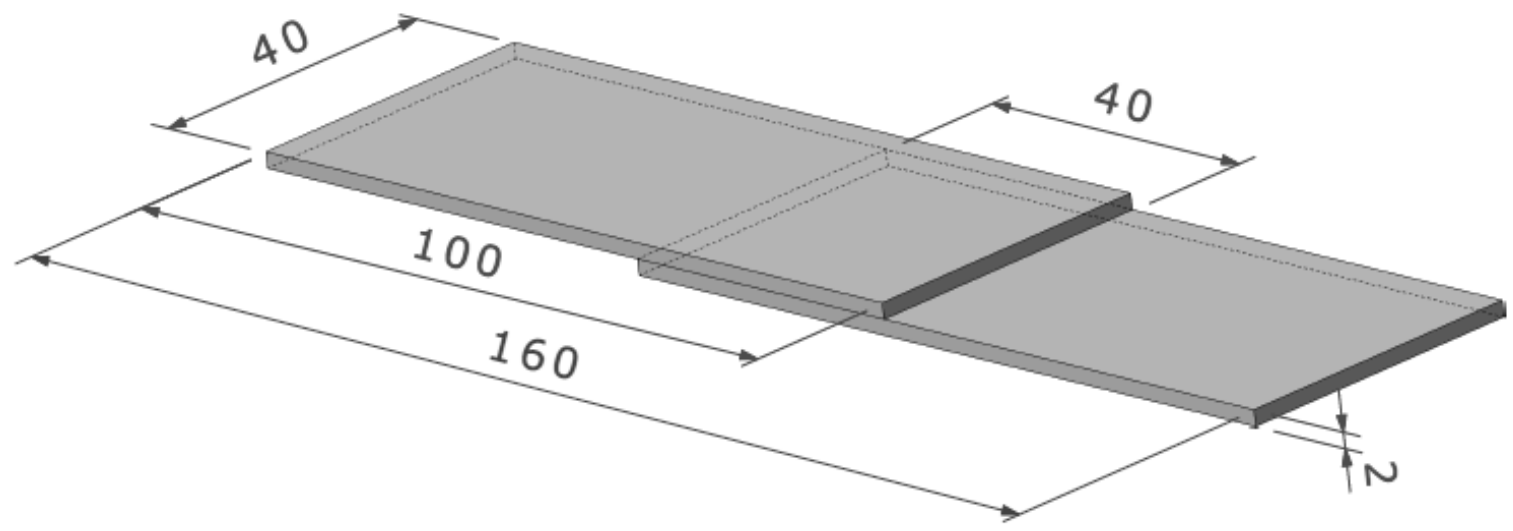

Fig. 1 Dimension of lap shear tensile specimen (all dimensions are in $\mathrm{mm}$ )

(a)

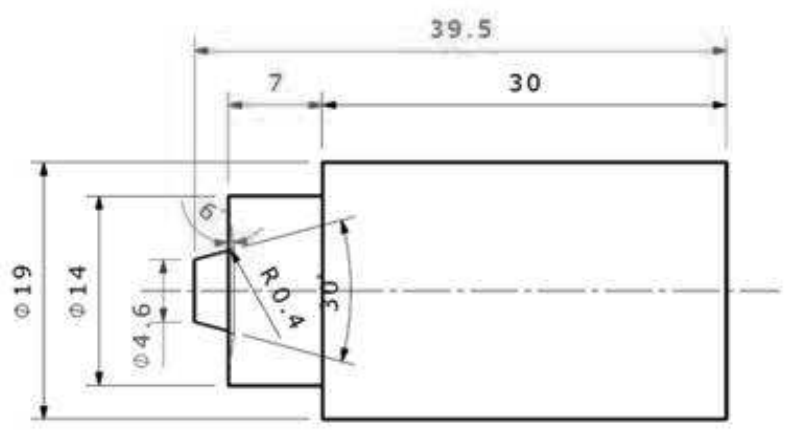

(b)

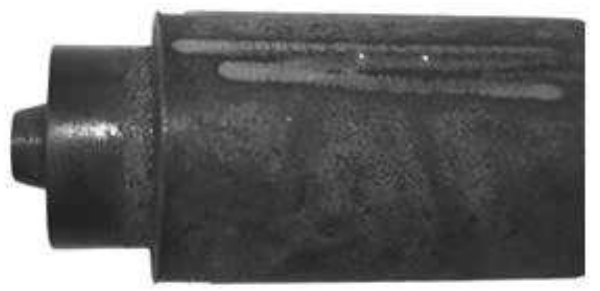

Fig. 2 Schematic (a) and actual (b) illustration of the tool used in FSSW process 


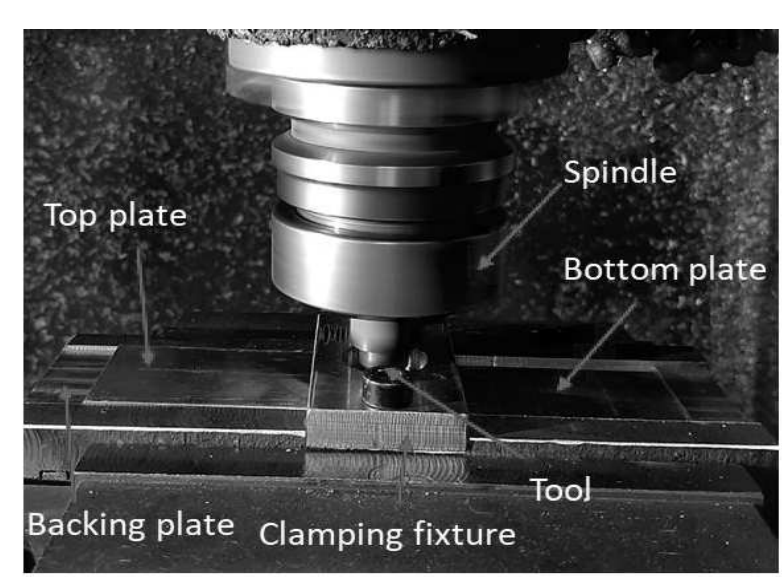

Fig. 3 The friction stir spot welding process setup

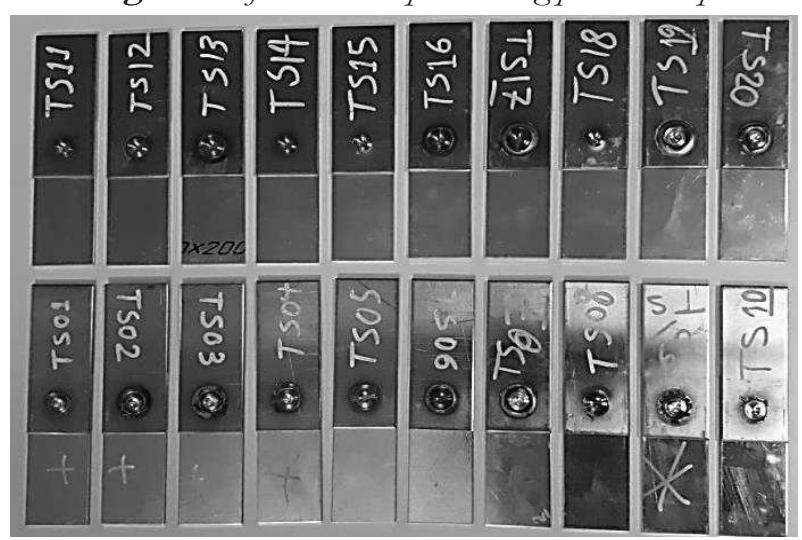

Fig. 4 The fabricated FSS welds

\subsection{Response Surface Methodology (RSM)}

Literature review revealed that tool rotation speed (R), dwell time (T) and tool plunge depth (D) have the major impacts on the quality of the jont produced by FSSW. In the present research, a three-factor and fivelevel central composite design (CCD) consisting of 20 run sets was used with the response surface methodology to model the experimental layout. This experimental layout allows to clarify the dependence of shear strength on various welding parameters and optimize welding operation. Table 3 displays the selected welding parameters and their proposed amounts. In all experiments, the optimum plunge rate of $10 \mathrm{~mm} / \mathrm{min}$ was chosen. Table 4 shows the experimental sequences and the responses (Shear Failure load- SFL) in this study. Experiments were conducted in random order to assure unbiased results for the given parametric settings (Table 4). The analysis has performed using "Design-expert 11" software and 95\% confidence level has been considered for the present analysis. A regression model has been generated to predict the SFL of the welds, depending on the parametric setting used. The second set of experiments were performed to validate the regression model. Numerical optimization toolbox of "Design-Expert 11" software has been used to predict the optimal parametric setting that can produce the weld with highest SFL.

Tab. 3 Welding parameters and their levels

\begin{tabular}{|c|c|c|c|c|c|c|c|c|c|}
\hline Factor & Name & Unit & Type & Minimum & Maximum & $\begin{array}{c}\text { Coded } \\
\text { Low }\end{array}$ & $\begin{array}{c}\text { Coded } \\
\text { High }\end{array}$ & Mean & $\begin{array}{l}\text { Std. } \\
\text { Dev. }\end{array}$ \\
\hline $\mathbf{A}$ & $\begin{array}{c}\text { Tool } \\
\text { rotational } \\
\text { speed }(\mathrm{R})\end{array}$ & $\mathrm{rpm}$ & Numeric & 500.00 & 2500.00 & $\begin{array}{c}-1 \leftrightarrow \\
1000.00\end{array}$ & $\begin{array}{c}+1 \leftrightarrow \\
2000.00\end{array}$ & 1500.00 & 458.83 \\
\hline B & $\begin{array}{l}\text { Dwell time } \\
\text { (T) }\end{array}$ & $\mathrm{s}$ & Numeric & 0.0000 & 8.00 & $\begin{array}{l}-1 \leftrightarrow \\
2.00\end{array}$ & $\begin{array}{c}+1 \leftrightarrow \\
6.00\end{array}$ & 4.00 & 1.84 \\
\hline C & $\begin{array}{c}\text { Plunge } \\
\text { depth (D) }\end{array}$ & $\mathrm{mm}$ & Numeric & 2.10 & 3.70 & $\begin{array}{l}-1 \leftrightarrow \\
2.50\end{array}$ & $\begin{array}{c}+1 \leftrightarrow \\
3.30\end{array}$ & 2.90 & 0.3671 \\
\hline
\end{tabular}

Shear testing of the welds indicates that weld strength varies for welds created with different experimental settings (Table 4). The highest obtained SFL was $6900 \mathrm{~N}$ for the run No. 6 (i.e., tool rotation speed 1500 $\mathrm{rpm}$, dwell time $4 \mathrm{~s}$ and tool plunge depth $3.7 \mathrm{~mm}$ ) whereas, the lowest SFL obtained is $600 \mathrm{~N}$ for the run No. 18 with tool rotation speed of $1500 \mathrm{rpm}, 4 \mathrm{~s}$ dwell time and $2.1 \mathrm{~mm}$ tool pin length. Therefore, SFL of friction stir spot-welded of AA1050 to C10100 copper alloy is a function of various welding parameters such as tool rotational speed (R), plunge depth (D), and dwell time $(\mathrm{T})$, as expressed in Eq. 1:

$$
S F L=f(R, D, T)
$$

Identifying and fitting an appropriate response surface model from experimental data requires knowledge of statistical experimental design fundamentals, regres-

sion modeling techniques, and elementary optimization methods. Central Composite Design (CCD) widely uses statistical methods based on multivariate nonlinear model for the optimization of FSSW process variables and also determines the regression equations and operating conditions from appropriate experiments. CCD is also useful for studying the interactions of various affecting process parameters (Karthikeyan \& Balasubramanian, 2010). CCD was applied in present study to determine the optimum process variables for friction stir spot welding process of $\mathrm{Al}$ to $\mathrm{Cu}$. It was also used for fitting a second-order model since it requires only a minimum number of experiments for modelling (MYERS et al., 2016). The optimization method essentially includes three main steps: (1) performing the statistically designed experiments; (2) estimating the coefficients of a mathematical model; and (3) predicting the response and testing 
the model's adequacy. An empirical model was developed to correlate the response to FSSW process and is based on second order quadratic model for friction stir spot welding of $\mathrm{Cu}$ to $\mathrm{Al}$ alloy as given by Eq. 2 .

Tab. 4CCD design matrix and experimental results

\begin{tabular}{|c|c|c|c|c|c|}
\hline & & Factor 1 & Factor 2 & Factor 3 & Response 1 \\
\hline STD & Run & $\begin{array}{c}\text { A: Tool rotational speed } \\
\mathrm{rpm}\end{array}$ & B: Dwell time & C: Plunge depth & $\begin{array}{l}\text { SFL } \\
\mathrm{kN}\end{array}$ \\
\hline 3 & 1 & 1000 & 6 & 2.5 & 1.9 \\
\hline 17 & 2 & 1500 & 4 & 2.9 & 6.53 \\
\hline 15 & 3 & 1500 & 4 & 2.9 & 6.58 \\
\hline 1 & 4 & 1000 & 2 & 2.5 & 2.3 \\
\hline 19 & 5 & 1500 & 4 & 2.9 & 6.67 \\
\hline 14 & 6 & 1500 & 4 & 3.7 & 6.8 \\
\hline 7 & 7 & 1000 & 6 & 3.3 & 5.26 \\
\hline 8 & 8 & 2000 & 6 & 3.3 & 6.9 \\
\hline 5 & 9 & 1000 & 2 & 3.3 & 6.29 \\
\hline 16 & 10 & 1500 & 4 & 2.9 & 6.7 \\
\hline 4 & 11 & 2000 & 6 & 2.5 & 4.18 \\
\hline 20 & 12 & 1500 & 4 & 2.9 & 6.51 \\
\hline 10 & 13 & 2500 & 4 & 2.9 & 4.21 \\
\hline 2 & 14 & 2000 & 2 & 2.5 & 4.1 \\
\hline 9 & 15 & 500 & 4 & 2.9 & 1.2 \\
\hline 18 & 16 & 1500 & 4 & 2.9 & 6.35 \\
\hline 12 & 17 & 1500 & 8 & 2.9 & 6.16 \\
\hline 13 & 18 & 1500 & 4 & 2.1 & 0.6 \\
\hline 6 & 19 & 2000 & 2 & 3.3 & 6.08 \\
\hline 11 & 20 & 1500 & 0 & 2.9 & 6.02 \\
\hline
\end{tabular}

Where:

$$
Y=\beta_{0}+\sum_{i=1}^{k} \beta_{i} x_{i}+\sum_{i=1}^{k} \sum_{j=1}^{k} \beta_{i j} x_{i} x_{j}+\sum_{i=1}^{k} \beta_{i i} x_{i i}^{2}+\varepsilon
$$

$\mathrm{Y}$ is the response variable;

$\boldsymbol{\beta}_{\mathbf{0}}$ is the intercept;

$\boldsymbol{\beta}_{\boldsymbol{i}}, \boldsymbol{\beta}_{\boldsymbol{i} \boldsymbol{j}}$ and $\boldsymbol{\beta}_{\boldsymbol{i} \boldsymbol{i}}$ are coefficients of linear effect, double interactions;

$\boldsymbol{x}_{\boldsymbol{i}}, \boldsymbol{x}_{\boldsymbol{j}}$ are the independent variables or factors and

$\boldsymbol{\varepsilon}$ is error.

\section{Results and Discussion}

\subsection{Developing an empirical equation}

The values of the coefficients in Eq. 2 were calculated using the Design Expert Software. The final central composite design obtained for SFL of the weldments with significant terms was a quadratic function shown in Eq. 3.

$\mathrm{SFL}=-59.42139+0.016783 \mathrm{R}-0.236349 \mathrm{~T}+32.57486 \mathrm{D}+0.000291 \mathrm{RT}+0.017187 \mathrm{TD}-0.001656 \mathrm{RD}$ $3.90136 \mathrm{E}-06 \mathrm{R}^{2}-0.032273 \mathrm{~T}^{2}-4.54119 \mathrm{D}^{2}$

Eq. 3 reveals how individual variables or double interaction influence SFL of friction stir spot weldments. The negative coefficient value indicates that SFL is negatively affected by individual or double interaction factors, whereas positive coefficient values increase SFL within the ranges tested.

\subsection{Analysis of Variance (ANOVA)}

The adequacy of models was justified by variance analysis (ANOVA) and listed in Table 5 and the summary of statistics are shown in Table 6. ANOVA of friction stir spot welding SFL is given in Table 7. The F-value of 190.61 implies the significance of model. The chance that this large amount of F-value could occur due to noise is $0.01 \%$. The model F-value is the ratio of mean square of any individual term to the mean square of the residual.

The model terms with $\mathrm{P}$-value less than 0.0500 are significant. Accordingly, A, C, AB, AC, BC, A2, B2 and $\mathrm{C} 2$ are significant model terms. On the other hand P-values greater than 0.1000 are not significant terms. The "F-value" of 4.79 implies not significant "Lack of Fit" value relative to pure error. The chance that this large amount of "Lack of Fit F-value" could occur due to noise is $5.53 \%$. Therefore, it can be concluded that tool rotational speed (A) and plunge depth (C) play important roles in SFL. It implied that a good correlation between input and output variables could be drawn by the developed model. The fitness of the de- 
veloped mathematical relation is evaluated using determination coefficient (R-Sq) and adjusted R-Sq (Table 8). The R-Sq value is computed considering every single variable explains the variations in the dependent variable, whereas adjusted R-Sq is computed by proposing the significant terms. The calculated R-Sq and adjusted R-Sq were 0.9895 and 0.9800 , respectively, indicating that the developed empirical relation is highly significant. The high value of estimated adjusted determination coefficient $\left(\boldsymbol{R}_{\boldsymbol{a} \boldsymbol{d} \boldsymbol{j}}^{\mathbf{2}}=0.9890\right)$ shows that $98.90 \%$ of the SFL data can be described by the selected model. The predicted $\mathrm{R}^{2}$ of 0.9633 is in reasonable agreement with the adjusted $\mathrm{R}^{2}$ of 0.9890 . The value of signal-to-noise ratio (adequate precision ratio) of 41.769 , indicates the model has an adequate signal. Since the adjusted determination coefficient and adequate precision ratio exceeded $70 \%$ and 4 respectively, the quadratic model can be used to explore the design space and to find the optimal conditions of this process.

Tab. 5 Adequacy of the model tested

\begin{tabular}{|c|c|c|c|c|c|c|}
\hline Source & Sum of Squares & $\mathrm{df}$ & Mean Square & F-value & P-value & \\
\hline Mean vs Total & 513.49 & 1 & 513.49 & & & \\
\hline Linear vs Mean & 45.68 & 3 & 15.23 & 7.21 & 0.0028 & \\
\hline 2FI vs Linear & 1.56 & 3 & 0.5193 & 0.2094 & 0.8881 & \\
\hline Quadratic vs $2 \mathrm{FI}$ & 31.78 & 3 & 10.59 & 229.98 & $<0.0001$ & Suggested \\
\hline Cubic vs Quadratic & 0.2995 & 4 & 0.0749 & 2.79 & 0.1261 & Aliased \\
\hline Residual & 0.1610 & 6 & 0.0268 & & & \\
\hline Total & 592.96 & 20 & 29.65 & & & \\
\hline
\end{tabular}

Tab. 6 Model summary statistics

\begin{tabular}{ccccccc}
\hline Source & Sum of Squares & df & Mean Square & F-value & P-value \\
\hline Linear & 33.71 & 11 & 3.06 & 192.68 & $<0.0001$ \\
2FI & 32.16 & 8 & 4.02 & 252.70 & $<0.0001$ & Suggested \\
Quadratic & 0.3810 & 5 & 0.0762 & 4.79 & 0.0553 & Aliased \\
Cubic & 0.0815 & 1 & 0.0815 & 5.12 & 0.0730 & \\
Pure Error & 0.0795 & 5 & 0.0159 & & & \\
\hline
\end{tabular}

Tab. 7 ANOV A of quadratic model for predicting tensile shear force loading

\begin{tabular}{|c|c|c|c|c|c|c|}
\hline Source & Sum of Squares & $\mathrm{df}$ & Mean Square & F-value & P-value & \\
\hline Model & 79.01 & 9 & 8.78 & 190.61 & $<0.0001$ & significant \\
\hline A-Tool rotational speed & 8.31 & 1 & 8.31 & 180.40 & $<0.0001$ & \\
\hline B-Dwell time & 0.00391 & 1 & 0.0039 & 0.0848 & 0.7768 & \\
\hline C-Plunge depth & 37.36 & 1 & 37.36 & 811.23 & $<0.0001$ & \\
\hline $\mathrm{AB}$ & 0.6786 & 1 & 0.6786 & 14.73 & 0.0033 & \\
\hline $\mathrm{AC}$ & 0.8778 & 1 & 0.8778 & 19.06 & 0.0014 & \\
\hline $\mathrm{BC}$ & 0.0015 & 1 & 0.0015 & 0.0328 & 0.8598 & \\
\hline $\mathrm{A}^{2}$ & 23.92 & 1 & 23.92 & 519.32 & $<0.0001$ & \\
\hline $\mathrm{B}^{2}$ & 0.4190 & 1 & 0.4190 & 9.10 & 0.0130 & \\
\hline$C^{2}$ & 13.27 & 1 & 13.27 & 288.20 & $<0.0001$ & \\
\hline Residual & 0.4606 & 10 & 0.0461 & & & \\
\hline Lack of Fit & 0.3810 & 5 & 0.0762 & 4.79 & 0.0553 & not significant \\
\hline Pure Error & 0.0795 & 5 & 0.0159 & & & \\
\hline Cor Total & 79.47 & 19 & & & & \\
\hline
\end{tabular}

Tab. $\boldsymbol{8}$ R-Sq, adjusted R-Sq and R-Sq prediction for developed model

\begin{tabular}{cccc}
\hline Std. Dev. & 0.2146 & R $^{2}$ & 0.9942 \\
\hline Mean & 5.07 & Adjusted R & 0.9890 \\
C.V. $\%$ & 4.24 & Predicted R & 0.9633 \\
& & Adeq Precision & 41.7688 \\
\hline
\end{tabular}


(a)

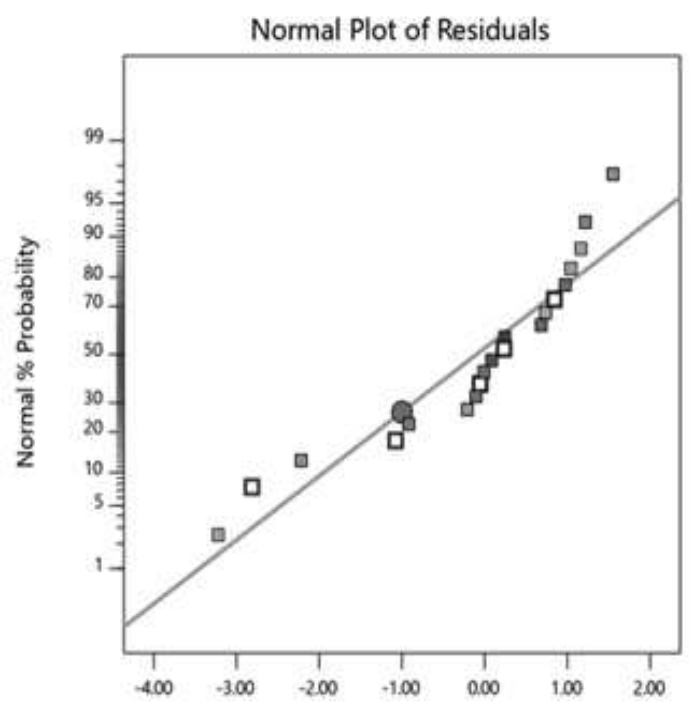

Externally Studentized Residuals

(c)

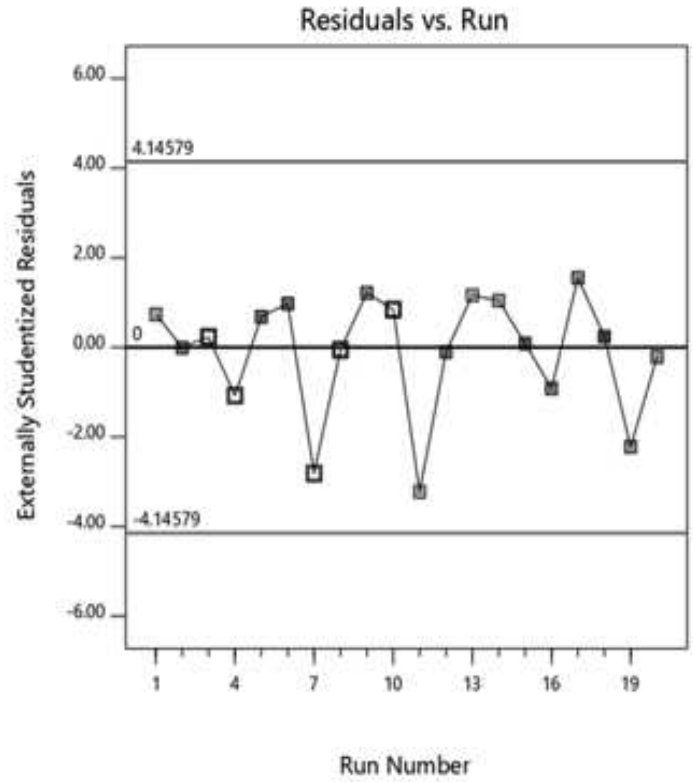

(b)

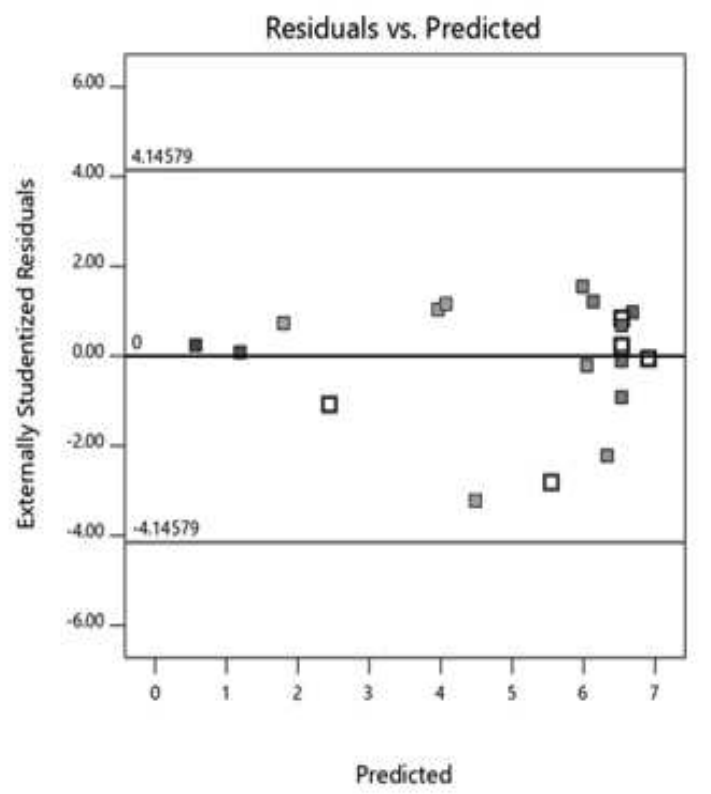

(d)

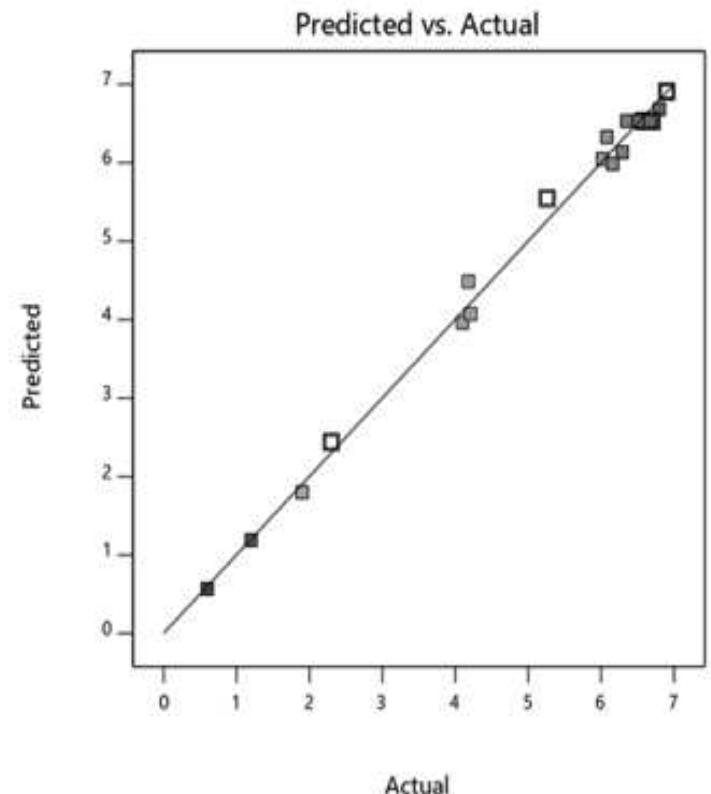

Fig. 5 Diagnostics plots of the developed model

Diagnostics plots of the developed model are depicted in Fig. 5. The normal probability plot indicates whether the residuals follow a normal distribution. Even with normal data, some scatter might be seen in the distribution of the depicted points. The corresponding normal probability plot for SFL of the joints (Fig. 5a) indicates the normal distribution of errors as they are closer to straight line. Residual vs. Predicted plot tests the assumption of constant variance. The plot should be a random scatter (constant range of residuals across the graph) which is in accordance with Fig. 5b. As can be seen from Fig. 5c, Residuals vs. Run plot checks for more affecting variables that may have influenced the response during the experiment. As shown in Fig. 5d, the experimental and predicted value of SFL for different parametric setting are efficiently in good agreement.

Cook's distance plot (Fig. 6a) is a measure of how much the entire regression function changes when the ith point is not included for fitting the model. It is essentially the sum of differences in predictions at every point caused by leaving a point out for fitting the model. Leverage plot (Fig. 6b) shows how each point influences the model fit. If a point has a leverage of 1.0, then the model exactly fits the observation at that point which controls the model. The results show that the leverage value was within $0-1$. 


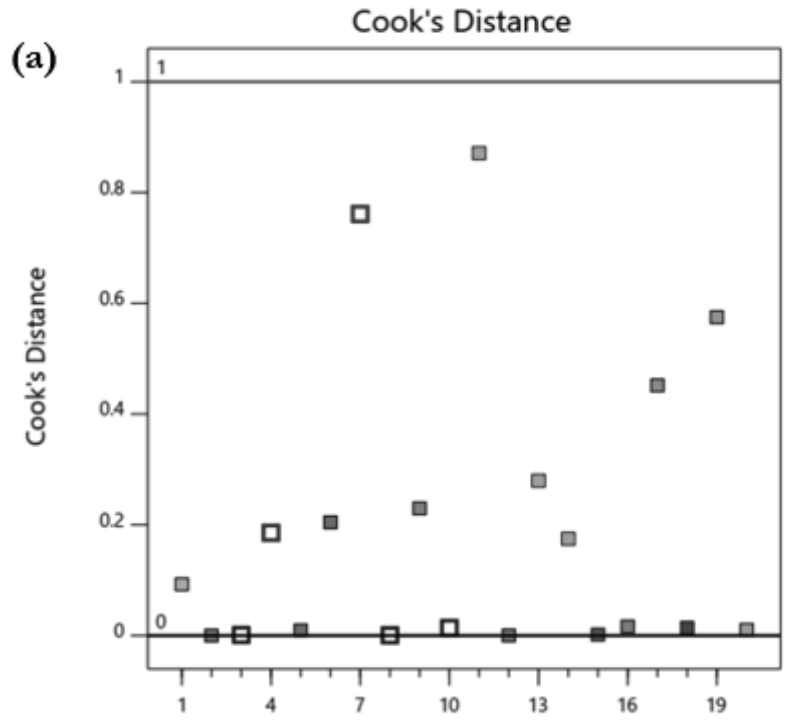

Run Number (b)

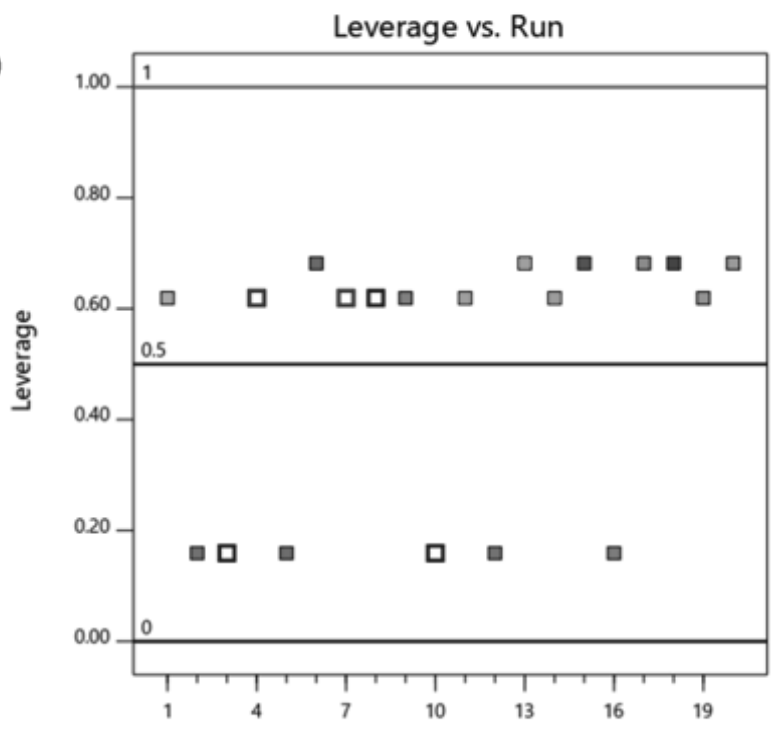

Run Number

Fig. 6 Cook's distance and leverage plot of the SFL data

\subsection{Effect of FSSW parameters on the SFL}

Design-Expert software offers various graphs to help visualize a selected model. The primary graphs for response surface design are 3D contour surfaces. Therefore, the influence of welding parameters and their interaction effects can be analyzed using 3D response graph and contour plots. The apex of response graph shows the maximum achievable SFL. A contour plot is produced to display the region of the optimal factor settings. The implemented 2nd-order plot looks more complex but more comprehensible compared to the simple series of parallel lines using first-order models. Contour plots play a very important role in the study of a response surface. The apex of the contour plots provides the optimal combination of parameters leading to maximum strength (SFL).

Fig. 7 and Fig. 8 show the 3D response graph and contour plots of tensile strength fracture load. The response surface graphs are drawn by varying two parameters and keeping the other parameter constant at middle range. Fig. 7 shows the response graph and contour plots for two varying parameters, i.e., tool rotational speed and dwell time (A vs. B) keeping plunge depth constant $(C=2.5,2.9$ and $3.3 \mathrm{~mm})$. The figure indicates that increasing tool rotational speed and dwell time initially escalate and then lessen the SFL. It is clear from Fig. 7 that the SFL value increases with increase in tool rotation speed and dwell time to its maximum because of increased heat input and sufficient material flow, and then decreases as the result of hook defect. This behavior of SFL has already been reported by other authors (Jannet et al., 2015; Pandey \& Mahapatra, 2019; Suryanarayanan \& Sridhar, 2020; Tozaki et al., 2008; Yuan et al., 2011). With lower dwell times, curves rise more rapid than the rise with higher dwell time. Meanwhile, low rotational speed and low dwelling time provide lower heat and in the absence of stirring operation, leading to inferior quality (Jannet et al., 2015). The results reveal that, at constant dwell time, increasing the tool rotational speed up to a certain level increases the SFL. Further increase in tool rotational speed reduces the SFL. For example, at constant dwell time of $4 \mathrm{~s}$ and plunge depth of $2.9 \mathrm{~mm}$, increasing the tool rotational speed from 500 to $1500 \mathrm{rpm}$ increases the shear force strength from 1.2 to $6.9 \mathrm{kN}$. Further increase in the tool rotational speed to $2500 \mathrm{rpm}$ reduces the SFL down to $4.21 \mathrm{kN}$. However, the SFL was observed to decrease almost after 1400 RPM (Fig. 7c) due to an increased generated heat (increased thermal exposure), which reduces the joint strength.

Yuan et al. (Yuan et al., 2011) showed that at lower rotational speed a larger bonded region was achieved with a relatively flat hooking that tends to vanish at the nugget area interface. Instead of disappearing at higher rpms, the hooking tended to curve upward on the outer edge of the nugget region which effectively decreases the bonded area. Different hooking feature stems from the difference in material flow at lower and higher rotation rates of the tool. During FSSW material undergoes extreme thermal cycle and plastic deformation. Through the coordination of the featured pin and tool shoulder, soft material is transferred downwards, then released and flows up into the stir region. This cycle continues until the tool is removed. Tool rotation rate influences material flow by varying the frictional heat input and volume of transported and released material that directly affects stir zone formation. They reported that the heat input increased 
with an increase in the tool rotational speed, which in turn reduced the material viscosity under the tool shoulder and around the pin, i.e. higher tool rotation rate leads to better material flow ability, thus more material displaced per unit time, and less shear and forging components needed by the tool for deforming the material. The boundary between stir zone and thermo mechanically affected zone changes slightly at lower tool rotational speed, and hooking is stirred and more dispersed. Nonetheless, sharp inner curved stir zone profile can be seen at a higher tool rotational speed and the hooking tends to be only extruded by the material released and then squeezed by downward material flow. The variation in lap-shear separation load with tool speed is related not only to the frictional heat, but also to the material flow which affects the size of bonded region and hooking features as well.

Moreover, at constant tool rotational speed, increasing the dwell time slightly increases and then decreases SFL. Dwell time plays a vital role in heat conduction, material flow, and expansion of nugget to form a stronger bond. Increasing the dwell time leads to an adequate heat conduction between the sheets and plasticization that improve material movement. However, escalation of dwell time after a certain level increases thermal cycle and reduces the joint's SFL (Suryanarayanan \& Sridhar, 2020). At lower dwell time, less heat is generated and as the dwell time increases, there will be more mixing and generated heat and consequently SFL of the weld rises slightly. Increased tool dwelling time, leads to excessive mixing and more heat is produced during the welding process which decreases the material flow stress. Zhang et al. (Zhang et al., 2011) reported that the joint strength of $\mathrm{Al} \mathrm{du-}$ ring FSSW process decreases by increasing rotational speed, while it's not affected significantly by dwell time. It can be concluded that due to enough friction between tool pin and shoulder and weld line, sufficient heat input can be achieved almost at the beginning of the friction stir spot welding cycle. Furthermore, due to increased thermal exposure, additional increase in dwell time slightly reduces the tensile strength of the welds.

Tool rotational speed and tool plunge depth are two primary sources of frictional heat during FSSW. Fig. 8a-f shows that increasing plunge depth initially escalates SFL to a certain value and further increasing plunge depth keeps SFL constant (Karthikeyan \& Balasubramanian, 2010). Weaker interfacial bonding is observed at lower magnitudes of plunge depth resulting lesser SFL. The obtained results revealed that when the plunge depth is less than $2.5 \mathrm{~mm}$, the frictional stir produced by tool is not sufficient to join the top and bottom sheets together and it produces defective joints. Rising the magnitude of plunge depth, leads to stronger interfacial bonding between the two sheets and increases the SFL of joint (Suryanarayanan
\& Sridhar, 2020).
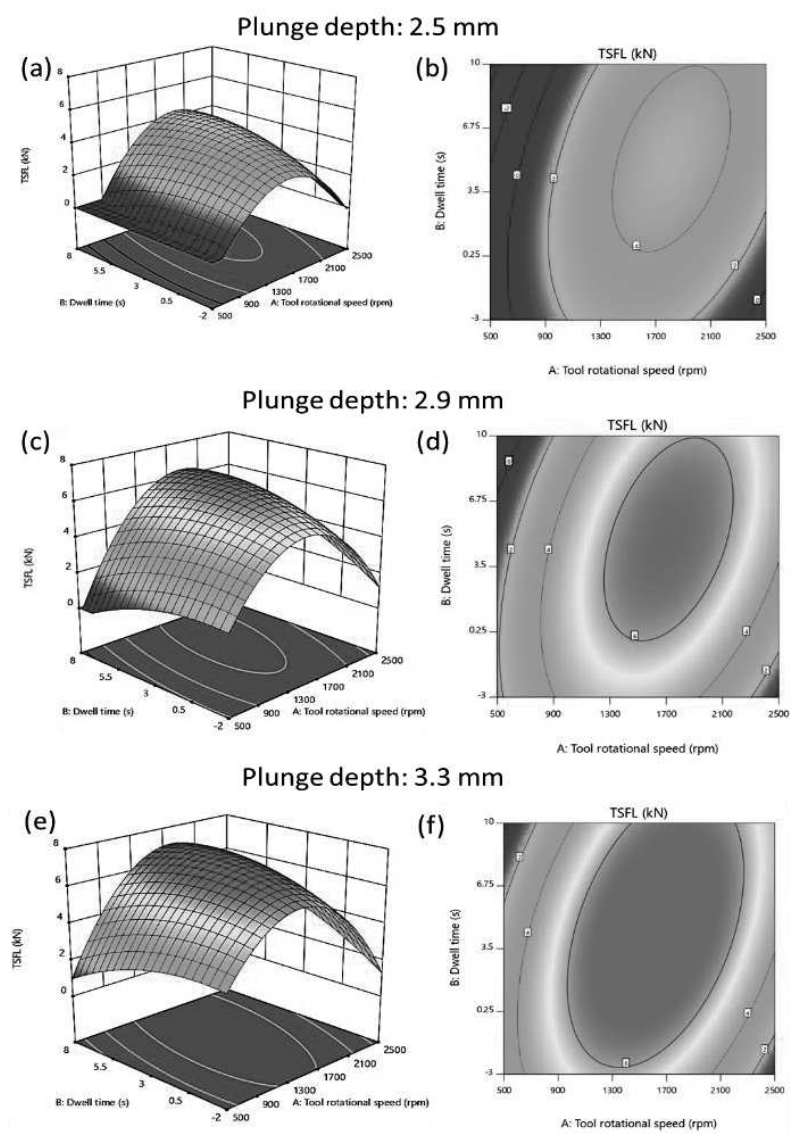

Fig. $7 \mathrm{R}-\mathrm{T} 3 \mathrm{D}$ response graph and contour plots at different plunge depths (a)

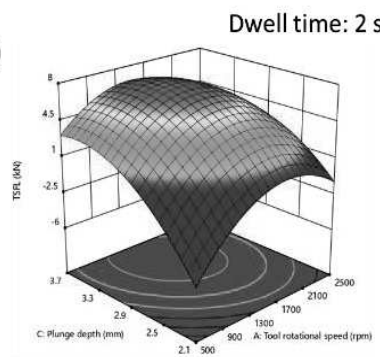

Dwell time: $4 \mathrm{~s}$

(c)

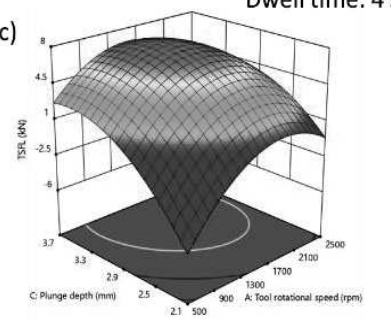

(e)

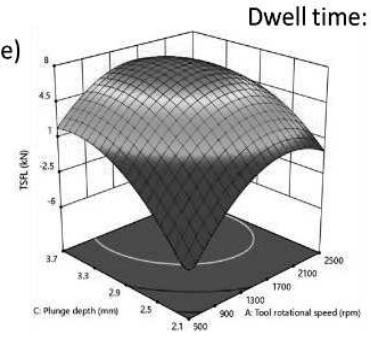

(b)

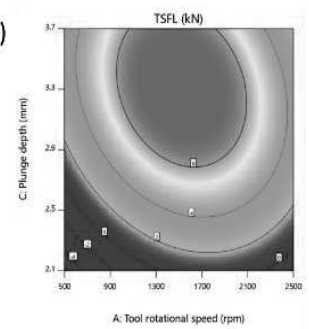

(d)

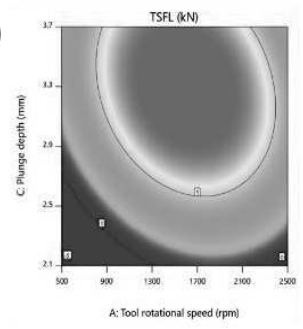

TSFL (KN)

(f)

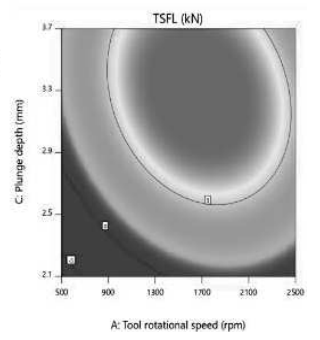

Fig. 8 R-D 3D response graph at different dwell times 
These findings indicate that the combination of rotational speed and depth of the tool plays a predominant role in determining the strength of FSSW joint and could substantially increase SFL. Excessive rotational speed, dwelling time and plunge depth generate higher heat and resulting metallurgical changes, i.e., grain coarsening, re-dissolution and coarsening of nugget-reinforcing precipitates. Lower dislocation density decreases the entire metallurgical bond region and consequently SFL value. Decreasing metallurgical bond width decreases SFL of the joint because of decrease in contact region between upper and lower sheets (Kastih et al., 2017; Mahmoud \& Khalifa, 2014). Due to larger keyhole and reduced overall metallurgical bond area, using plunge depths greater than $3.7 \mathrm{~mm}$ would lead to weaker interfacial bonding.

Yoon et al. [4] have observed that increase in plunge depth leads to increase in FSL. In addition to increase in FSL, tool plunge depth is a very important parameter for controlling the surface appearance of the welded zone. Increasing tool plunge depth leads to increase in the amount of burr and decrease in the thickness at the central region of welded zone of the lower plate. This result suggests that by increasing tool plunge depth, plastic deformation of material near the welded zone is escalated (Yoon et al., 2012). As depicted in Fig. 9, the amount of burr is less for sample No. 18 (Fig. 9a) compare to sample No. 2 (Fig. 9b) with the plunge depths of 2.1 and $2.9 \mathrm{~mm}$ respectively. (a)

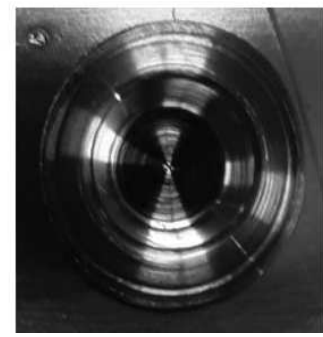

(b)

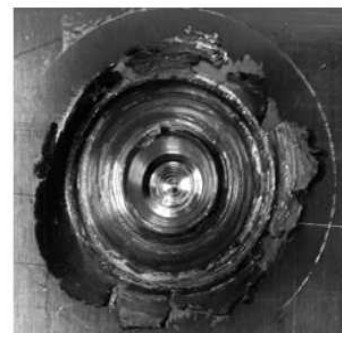

Fig. 9 Effect of plunge depth on weld appearance; (a) 2.1 mm, (b) $2.9 \mathrm{~mm}$

The contributions made by process parameters on FSL may also be determined during this research. The higher $\mathrm{F}$ ratio value in Table 7 implies that the respective term is more significant and vice versa. Consequently, it can be concluded that plunge depth contributes more on FSL, followed by tool rotational speed and dwell time for the range considered in this investigation.

The effect of various welding factors (process variables) on the response is presented in perturbation plot. The perturbation plot compares the effect of all factors at a particular point in design space. The response is plotted by changing only one factor over its range while holding other factors constant. By default, Design-Expert sets the reference point at the midpoint of all other factors. A steep slope or curvature of a factor shows that the response is sensitive to that factor. A relatively flat line shows insensitivity to any changes of that particular factor. If there are more than two factors, the perturbation plot could be used to find those factors that most affect the response. The perturbation plot for the response SFL of the FSSW (Fig. 10) revealed a sequence of relative influence of the operating parameters on the target response as follows: Plunge depth $>$ Tool rotational speed $>$ Dwell time. Therefore it can be inferred that the SFL varies significantly with changes of plunge depth and tool rotational speed, whereas SFL does not change significantly with variation in dwell time.

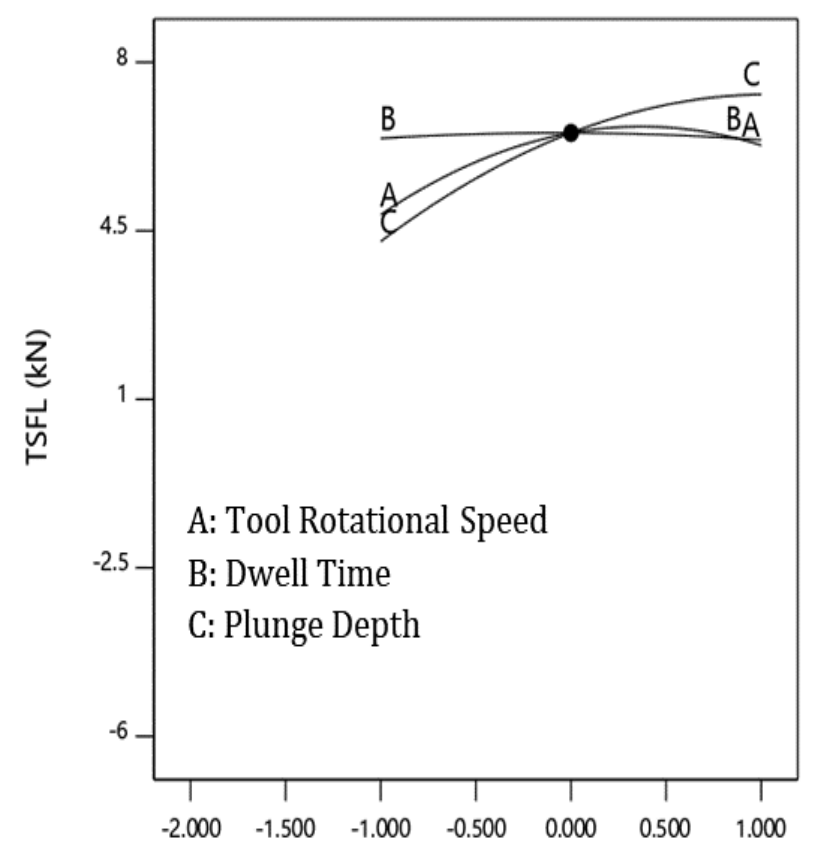

Deviation from Reference Point (Coded Units)

Fig. 10 Perturbation plot showing the effect of factors (process variables of Table 1)

3.4 Optimizing FSSW process parameters using desirability function

During numerical optimization, the desired objective for each factor and response is chosen. A weight can be assigned to each objective to adjust the shape of its particular desirability function. The objectives are combined into an overall desirability function. Desirability is an objective function that ranges from zero outside of the limits, to one at the goal. Design Expert software seeks to maximize this function. The goal seeking begins at a random starting point and proceeds up the steepest slope to a maximum. There may be two or more maximums because of curvature in the response surfaces and their combination in the desirability function. Starting from several points in the design space search gradually proceeds to increase the chances of finding the 'best' local maximum. 
(a)
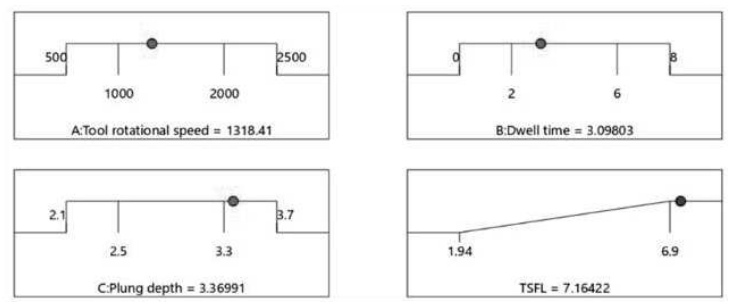

(b)

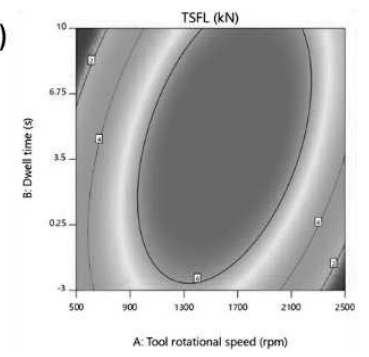

Fig. 11 Desirability ramp of SFL

A multiple response method was applied for optimization of SFL. Fig. 11a demonstrates the desirability values of the numerical optimization procedure in which the criterion was set, "in range" for tool plunge depth, rotational speed and dwell time, and maximum SFL. Moreover position of the best local maximum is shown over the related contour plot (Fig. 11b). The objective of this process was to find the maximum FSL of the weldments by utilizing process variables.
By seeking from 20 starting points (Diagnostic case statistics, Table 9) within the responses, the best local maximum was found at tool rotational speed of 1318 rpm, dwell time of $3.1 \mathrm{~s}$ and plunge depth of $3.3 \mathrm{~mm}$. At this condition SFL of the weldments is close to 7.16 $\mathrm{kN}$ and desirability of 1.00 .

\subsection{Validation}

Three tests were performed with the optimal combination of tool rotational speed, dwell time and plunge depth to validate the optimization procedure. Accordingly, various joints using $\mathrm{Cu} \mathrm{Al}$ sheets were joint with FSSW process. Table 10 shows a summary of calculated optimal solution of process parameters and responses (according to Fig. 11). After the test, the dissimilar $\mathrm{Al} / \mathrm{Cu} \mathrm{FSSW}$ joints were subjected to tensile test. The average of the three confirmation tests for the dependent variables are also shown in Table 10. The results show that the optimal results of the SFL was close to the optimal solution obtained from the mathematical model. The percentage of error was calculated between the optimal solution and the average confirmation test results. The validation results revealed that the developed optimization procedure is quite accurate and the percentage of error was within the acceptable range (Table 10). Fig. 12 shows the variation of tensile force vs displacement of the fabricated weldments in optimum condition.

Tab. 9 Diagnostics case statistics

\begin{tabular}{|c|c|c|c|c|c|c|c|c|}
\hline $\begin{array}{l}\text { Run } \\
\text { Order }\end{array}$ & $\begin{array}{l}\text { Actual } \\
\text { Value }\end{array}$ & $\begin{array}{l}\text { Predicted } \\
\text { Value }\end{array}$ & $\begin{array}{l}\text { Resid- } \\
\text { ual }\end{array}$ & $\begin{array}{l}\text { Lev- } \\
\text { erage }\end{array}$ & $\begin{array}{c}\text { Internally Stu- } \\
\text { dentized Resid- } \\
\text { uals }\end{array}$ & $\begin{array}{c}\text { Externally Stu- } \\
\text { dentized Residu- } \\
\text { als }\end{array}$ & $\begin{array}{c}\text { Cook's } \\
\text { Distance }\end{array}$ & $\begin{array}{c}\text { Standard } \\
\text { Order }\end{array}$ \\
\hline 1 & 1.90 & 1.80 & 0.0998 & 0.619 & 0.754 & 0.736 & 0.092 & 3 \\
\hline 2 & 6.53 & 6.53 & -0.0018 & 0.159 & -0.009 & -0.009 & 0.000 & 17 \\
\hline 3 & 6.58 & 6.53 & 0.0482 & 0.159 & 0.245 & 0.233 & 0.001 & 15 \\
\hline 4 & 2.30 & 2.44 & -0.1414 & 0.619 & -1.068 & -1.076 & 0.186 & 1 \\
\hline 5 & 6.67 & 6.53 & 0.1382 & 0.159 & 0.702 & 0.683 & 0.009 & 19 \\
\hline 6 & 6.80 & 6.68 & 0.1183 & 0.682 & 0.977 & 0.975 & 0.205 & 14 \\
\hline 7 & 5.26 & 5.55 & -0.2864 & 0.619 & -2.163 & -2.813 & 0.761 & 7 \\
\hline 8 & 6.90 & 6.91 & -0.0077 & 0.619 & -0.058 & -0.055 & 0.001 & 8 \\
\hline 9 & 6.29 & 6.13 & 0.1573 & 0.619 & 1.188 & 1.216 & 0.230 & 5 \\
\hline 10 & 6.70 & 6.53 & 0.1682 & 0.159 & 0.855 & 0.842 & 0.014 & 16 \\
\hline 11 & 4.18 & 4.49 & -0.3064 & 0.619 & -2.314 & -3.221 & 0.871 & 4 \\
\hline 12 & 6.51 & 6.53 & -0.0218 & 0.159 & -0.111 & -0.105 & 0.000 & 20 \\
\hline 13 & 4.21 & 4.07 & 0.1383 & 0.682 & 1.142 & 1.162 & 0.280 & 10 \\
\hline 14 & 4.10 & 3.96 & 0.1373 & 0.619 & 1.037 & 1.042 & 0.175 & 2 \\
\hline 15 & 1.20 & 1.19 & 0.0108 & 0.682 & 0.089 & 0.085 & 0.002 & 9 \\
\hline 16 & 6.35 & 6.53 & -0.1818 & 0.159 & -0.924 & -0.916 & 0.016 & 18 \\
\hline 17 & 6.16 & 5.98 & 0.1758 & 0.682 & 1.452 & 1.551 & 0.452 & 12 \\
\hline 18 & 0.6000 & 0.5692 & 0.0308 & 0.682 & 0.254 & 0.242 & 0.014 & 13 \\
\hline 19 & 6.08 & 6.33 & -0.2489 & 0.619 & -1.880 & -2.218 & 0.575 & 6 \\
\hline 20 & 6.02 & 6.05 & -0.0267 & 0.682 & -0.221 & -0.210 & 0.010 & 11 \\
\hline
\end{tabular}




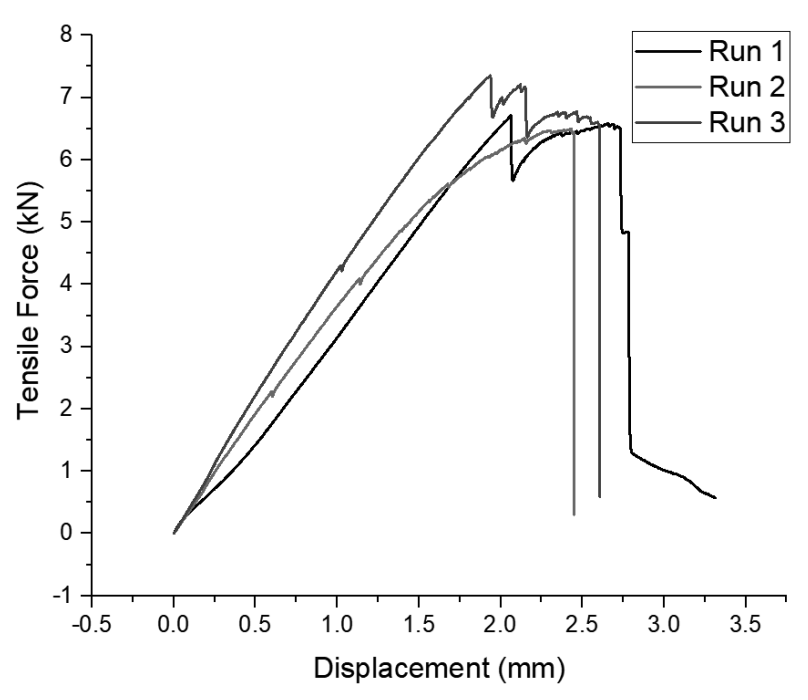

Fig. 12 Force vs displacement of the weldments

\section{Conclusion}

- Dissimilar AA1050 aluminum alloy and C10100 copper friction stir spot welding experiments were conducted and three significant process parameters such as tool rotational speed, plunge depth and dwelling time were established to influence joint quality.

- An empirical relationship for the prediction of tensile shear failure strength of dissimilar joints was developed with 95\% confidence level from incorporated friction stir spot welding parameters.

- Using response surface methodology, optimum process parameters leading to maximum FSL were determined and the responses were evaluated for predicting the optimum values using surface and contour plots.

- Analysis of Goodness-of-fit values show that the $\mathrm{R} 2$, adjusted $\mathrm{R} 2$ and predicted $\mathrm{R} 2$ values are $0.9942,0.9890$ and 0.9633 respectively, indicating how well the model fits with the produced experimental data.

- Average maximum obtained tensile shear failure load was $7.07 \mathrm{kN}$ and the corresponding values of process parameters were tool rotational speed of $1318 \mathrm{rpm}$, dwell time of $3.1 \mathrm{~s}$, plunge depth of $3.3 \mathrm{~mm}$.

- Upon validation of the optimization model, the percentage error between predicted and actual values was less than $4 \%$, which suggests a rather good model predictability.

- The proposed approach can be used to determine optimum FSSW parameters of other dissimilar materials with various thicknesses.

Tab. 10 Optimal parameters and confirmation test results

\begin{tabular}{ccccc}
\hline Experiment & $\begin{array}{c}\text { Tool rotational } \\
\text { speed (rpm) }\end{array}$ & Dwell time (s) & Plunge depth (mm) & SFL (kN) \\
\hline Optimal solution & 1318 & 3.1 & 3.3 & 7.16 \\
Run 1 & 1318 & 3.1 & 3.3 & 6.71 \\
Run 2 & 1318 & 3.1 & 3.3 & 6.5 \\
Run 3 & 1318 & 3.1 & 3.3 & 7.35 \\
Average confirma- & & & & 7.07 \\
tion test results & & & & 4 \\
Percentage error & & & \\
$(\%)$ & & & \\
\hline
\end{tabular}

\section{Acknowledgement}

\section{Authors wish to thank the university of kashan for} the financial support of this research.

\section{References}

[1] ABBASS, MUNA K., SABAH KH HUSSEIN, AND A. A. K. (2015). Optimization of friction stir spot welding parameters of dissimilar welded joints of aluminum alloy (AA2024T3) with pure copper sheets. In: International journal of engineering sciences\& research technology, Vol. 9655, No. 12, pp.514-526. India. 2278-0181
[2] CHU, Q., LI, W. Y., YANG, X. W., SHEN, J. J., VAIRIS, A., FENG, W. Y., \& WANG, W. B. (2018). Microstructure and mechanical optimization of probeless friction stir spot welded joint of an Al-Li alloy. In: Journal of Materials Science and Technology, Vol. 34, No. 10, pp. 1739_ 1746. United States. 1005-0302

[3] COLMENERO, A. N., OROZCO, M. S., MACÍAS, E. J., FERNÁNDEZ, J. B., MURO, J. C. S. D., FALS, H. C., \& ROCA, A. S. (2019). Optimization of friction stir spot welding process parameters for $\mathrm{Al}-\mathrm{Cu}$ dissimilar joints 
using the energy of the vibration signals. In: International Journal of Advanced Manufacturing Technology, Vol. 100, No. 9-12, pp. 2795-2802. United Kingdom. 1433-3015

[4] GARG, A., \& BHATTACHARYA, A. (2017). Strength and failure analysis of similar and dissimilar friction stir spot welds: Influence of different tools and pin geometries. In: Materials and Design, Vol. 127, pp. 272-286. Netherlands. 0264-1275

[5] DOBRoCky, D., DOSTAL, P., SUSTR, M., POKORNY, Z., STUDENY, Z. (2018), Analysis of weld joint of DX51D steel with AlMg3 alloy made by CMT welding method. In: Manufacturing Technoly, Vol.18, No.2, pp. 215-221. Czech Republic. 1213-2489.

[6] HEIDARZADEH, A., LALEH, H. M., GERAMI, H., HOSSEINPOUR, P., SHABESTARI, M. J., \& BAHARI, R. (2018). The origin of different microstructural and strengthening mechanisms of copper and brass in their dissimilar friction stir welded joint. In: Materials Science and Engineering A, Vol. 735, No. August, pp. 336-342. Netherlands. 0921-5093

[7] HEIDEMAN, R., JOHNSON, C., \& KOU, S. (2010). Metallurgical analysis of $\mathrm{Al} / \mathrm{Cu}$ friction stir spot welding. In: Science and Technology of Welding and Joining, Vol. 15, No. 7, pp. 597-604. United Kingdom. 1743-2936

[8] JANNET, S., MATHEWS, P. K., \& RAJA, R. (2015). Optimization of process parameters of friction stir welded AA 5083-O aluminum alloy using Response Surface Methodology. In: Bulletin of the Polish Academy of Sciences: Technical Sciences, Vol. 63, No. 4, pp. 851-855. Poland. 23001917

[9] KARTHIKEYAN, $\quad$ R., \& BALASUBRAMANIAN, V. (2010). Predictions of the optimized friction stir spot welding process parameters for joining AA2024 aluminum alloy using RSM. In: International Journal of Advanced Manufacturing Technology, Vol. 51, No. 1-4, pp. 173-183. United Kingdom. 1433-3015

[10] KASTIH, V. T. O., AL, Z., MUBIAYI, M. P., AKINLABI, E. T., \& MAKHATHA, M. E. (2017). Microstructure Evolution And Statistical Analysis Of $\mathrm{Al} / \mathrm{Cu}$ Friction-Stir Spot Welds. In: Materials and technology, Vol. 51, No. 5, pp. 861-869. Slovenia. 1580-3414

[11] KLOBČAR, D., TUŠEK, J., SKUMAVC, A., \& SMOLEJ, A. (2014). Parametric study of friction stir spot welding of aluminium alloy
5754. In: Metalurgija, Vol. 53, No. 1, pp. 21-24. Croatia. 0543-5846

[12] KLOBČAR, D., TUŠEK, J., SMOLEJ, A., \& SIMONČIČ, S. (2014). Parametric study of FSSW of aluminium alloy 5754 using a pinless tool. In: Welding in the World, Vol. 59, No. 2, pp. 269-281. Germany. 00432288

[13] KULEKCI, M. K. (2014). Effects of process parameters on tensile shear strength of friction stir spot welded aluminium alloy (EN AW 5005). In: Archives of Metallurgy and Materials, Vol. 59, No. 1, pp. 221-224. Poland. 17333490

[14] LI, M., ZHANG, C., WANG, D., ZHOU, L., WELLMANN, D., \& TIAN, Y. (2020). Friction stir spot welding of aluminum and copper: A review. In: Materials, Vol. 13, No. 1, pp. 156. Switzerland. 1996-1944

[15] MAHMOUD, T. S., \& KHALIFA, T. A. (2014). Microstructural and mechanical characteristics of aluminum alloy AA5754 friction stir spot welds. In: Journal of Materials Engineering and Performance, Vol. 23, No. 3, pp. 898-905. United States. 1059-9495

[16] MANICKAM, S., \& BALASUBRAMANIAN, V. (2015). Maximizing Strength of Friction Stir Spot Welded Bimetallic Joints of AA6061 Aluminum Alloy and Copper Alloy by Response Surface. In: Int J mech Eng, Vol. 3, No. 12, pp. 15-26. United Kingdom. 0020-7403

[17] MATA, F., BEAMUD, E., HANAFI, I., KHAMLICHI, A., JABBOURI, A., \& BEZZAZI, M. (2010). Multiple Regression Prediction Model for Cutting Forces in Turning Carbon-Reinforced PEEK CF30. In: Advances in Materials Science and Engineering, Vol. 2010. Egypt. 16878442

[18] MILLER, W. S., ZHUANG, L., BOTTEMA, J., WITTEBROOD, A. J., DE SMET, P., HASZLER, A., \& VIEREGGE, A. (2000). Recent development in aluminium alloys for the automotive industry. In: Materials Science and Engineering A, Vol. 280, No. 1, pp. 37-49. Netherlands. 0921-5093

[19] MUBIAYI, M. P., \& AKINLABI, E. T. (2016). Evolving properties of friction stir spot welds between AA1060 and commercially pure copper C11000. In: Transactions of Nonferrous Metals Society of China (English Edition), Vol. 26, No. 7, pp. 1852-1862. China. 1003-6326

[20] MUBIAYI, M. P., AKINLABI, E. T., \& MAKHATHA, M. E. (2019). Current Trends in Friction Stir Welding (FSW) and Friction Stir 
Spot Welding (FSSW) (Vol. 6). Springer, 978-3319-92750-3

[21] MYERS, R. H., MONTGOMERY, D. C., \& ANDERSON-COOK, C. M. (2016). Design Of Experiments For Fitting Response Surfaces-I. In: Response surface methodology (Fourth Edition), pp. 369-450. WILEY, 978-1-11891601-8

[22] ÖZDEMIR, U., SAYER, S., \& YENI, Ç. (2012). Effect of pin penetration depth on the mechanical properties of friction stir spot welded aluminum and copper. In: Materialpruefung/Materials Testing, Vol. 54, No. 4, pp. 233 239. Germany. 00255300

[23] PANDEY, A. K., \& MAHAPATRA, S. S. (2019). Investigation of weld zone obtained by friction stir spot welding (FSSW) of aluminium6061 alloy. In: Materials Today: Proceedings, Vol. 18, pp. 4491-4500. United Kingdom. 22147853

[24] PÉREZ, M., PARTE, D., AZOFRA, J. C., DOMINGO, H., FALS, C., ROCA, A. S., CÉSAR, M., OROZCO, S., \& MACÍAS, E. J. (2019). A new way to predict the mechanical properties of friction stir spot welding for $\mathrm{Al}$ $\mathrm{Cu}$ joints by energy analysis of the vibration signals. In: The International Journal of Advanced Manufacturing Technology, Vol. 105, No.1, pp. 18231834. 1433-3015

[25] R. PADMANABAN, R. VAIRA VIGNESH, M. ARIVARASU, K. K. P. AND A. A. S. (2016). PROCESS PARAMETERS EFFECT ON THE STRENGTH OF FRICTION STIR SPOT WELDED AA6061. In: ARPN Journal of Engineering and Applied Sciences, Vol. 11, No. 9, pp. 6030-6035. Pakistan. 18196608

[26] R. PALANIVEL, I. DINAHARAN, AND R. F. L. (2019). Friction Stir Spot Welding of Similar and Dissimilar Nonferrous Alloys, In: $A d-$ vances in Welding Technologies for Process Development, pp. 159-190. CRC Press. 9780367656515

[27] SAHLOT, P., SINGH, A. K., BADHEKA, V. J., \& ARORA, A. (2019). Friction Stir Welding of Copper: Numerical Modeling and Validation. In: Transactions of the Indian Institute of $M e-$ tals, Vol.72, pp.1339-1347. India. 09722815

[28] SEJČ, P., BELANOVÁ, J., GÁBRIŠOVÁ, Z., VANKO, B. (2020). The Influence of Parameters of the Resistance Projection Welding of M10 Steel Nuts to the Galvanized Steel Sheet DP 600 on Selected Joint Characteristics, In: Manufacturing Tecbnoly, Vol. 20, No.6, pp. 822833. Czech Republic. 1213-2489.
[29] SHIRALY, M., SHAMANIAN, M., TOROGHINEJAD, M. R., \& AHMADI JAZANI, M. (2014). Effect of tool rotation rate on microstructure and mechanical behavior of friction stir spot-welded $\mathrm{Al} / \mathrm{Cu}$ composite. In: Journal of Materials Engineering and Performance, Vol. 23, No. 2, pp. 413-420. United States. 10599495

[30] SHIRALY, M., SHAMANIAN, M., TOROGHINEJAD, M. R., JAZANI, M. A., \& SADREDDINI, S. (2017). The Influence of Tool Geometry on the Mechanical Behaviour of FSSWed $\mathrm{Al} / \mathrm{Cu}$ ARBed Composite. In: Transactions of the Indian Institute of Metals, Vol. 70, No. 8, pp. 2205-2211. India. 09722815

[31] SIDDHARTH, S., \& SENTHILKUMAR, T. (2016). Optimization of Friction Stir Spot Welding Process Parameters of Dissimilar Al 5083 and C 10100 Joints Using Response Surface Methodology. In: Russian journal of non-ferrous metals, Vol. 57, No. 5, pp. 456-466. Russian Federation. 1934970X

[32] SIDDHARTH, S., \& SENTHILKUMAR, T. (2017). Study of tool Penetration Behavior in Dissimilar Al5083 /C10100 Friction Stir Spot Welds. In: Procedia Engineering, Vol. 173, pp. 1439-1446. Netherlands. 18777058

[33] SIDDHARTH, S., \& SENTHILKUMAR, T. (2018). Optimizing Process Parameters for Increasing Corrosion Resistance of Friction Stir Spot Welded Dissimilar Al-5086/C10100 Joints. In: Transactions of the Indian Institute of $\mathrm{Me}$ tals, Vol. 71, No. 4, pp. 1011-1024. India. 09722815

[34] SIDDHARTH, S., SENTHILKUMAR, T., \& CHANDRASEKAR, M. (2017). Development of processing windows for friction stir spot welding of aluminium Al5052 / copper C27200 dissimilar materials. In: Transactions of Nonferrous Metals Society of China (English Edition), Vol. 27, No. 6, pp. 1273-1284. China. 10036326

[35] SUN, H., ZHOU, Q., ZHU, J., \& PENG, Y. (2017). Analysis on the Fracture of Al-Cu Dissimilar Materials Friction Stir Welding Lap Joint. In: Journal of Materials Engineering and Performance, Vol. 26, No. 12, pp. 5715-5722. United States. 10599495

[36] SURYANARAYANAN, R., \& SRIDHAR, V. G. (2020). Effect of Process Parameters in Pinless Friction Stir Spot Welding of Al 5754-Al 6061 Alloys. In: Metallography, Microstructure, and Analysis, pp. 1-12. United States. 21929262 
[37] TOZAKI, Y., UEMATSU, Y., \& TOKAJI, K. (2008). Effect of tool shoulder diameter on mechanical properties of friction stir spot welded joints. In: Transactions of the Japan Society of Mechanical Engineers, Part A, Vol. 74, No. 2, pp. 268274. Japan. 13475363

[38] YOON, S., KANG, M., KWON, Y., HONG, S., PARK, D., LEE, K., LIM, C., \& SEO, J. (2012). Influences of tool plunge speed and tool plunge depth on friction spot joining of AA5454-O aluminum alloy plates with different thicknesses. In: Transactions of Nonferrous Metals Society of China, Vol. 22, pp. 629-633. China. 10036326
[39] YUAN, W., MISHRA, R. S., WEBB, S., CHEN, Y. L., CARLSON, B., HERLING, D. R., \& GRANT, G. J. (2011). Effect of tool design and process parameters on properties of $\mathrm{Al}$ alloy 6016 friction stir spot welds. In: Journal of Materials Processing Technology, Vol. 211, pp. 972977. Netherlands. 09240136

[40] ZHANG, Z., YANG, X., ZHANG, J., ZHOU, G., XU, X., \& ZOU, B. (2011). Effect of welding parameters on microstructure and mechanical properties of friction stir spot welded 5052 aluminum alloy. In: Materials and Design, Vol. 32, No. 8-9, pp. 4461-4470. Netherlands. 0264-1275 